\title{
Penerapan Metode Picture and Picture pada Pembelajaran Menulis Teks Deskripsi
}

\author{
Wahyu Prapti Yuliana ${ }^{*}$, Utami², Larasati $^{3}$ \\ 123 Program Studi S1 Bimbigan dan Konseling FKIP - Universitas Kristen Satya Wacana
}

\begin{abstract}
Abstrak
Tujuan Penelitian ini dilatarbelakangi berdasarkan keterampilan menulis masih rendah atau di bawah rata-rata pada siswa kelas VII SMP N 2 Kedu Temanggung, khususnya menulis teks deskripsi. Melihat kondisi tersebut, perlu diupayakan penggunaan model pembelajaran tertentu untuk menumbuhkan motivasi siswa dalam pembelajaran menulis teks deskripsi pada siswa kelas VII SMP N 2 Kedu Temanggung. Salah satunya dengan penerapan model Picture and Picture.Rumusan masalah dalam penelitian ini adalah bagaimanakah penerapan model Picture and Picture dalam pembelajaran menulis teks deskripsi pada siswa kelas VII SMP N 2 Kedu Temanggung tahun ajaran 2018/2019?. Ada pun tujuan dari penelitian ini mendeskripsikan penerapan model Picture and Picture dalam pembelajaran menulis teks deskripsi pada siswa kelas VII SMP N 2 Kedu Temanggung tahun ajaran 2018/2019. Bentuk penelitian menggunakan metode kualitatif. Teknik pengumpulan data menggunakan teknik tes untuk mengetahui hasil menulis teks deskripsi menggunakan model Picture and Picture dan teknik nontes menggunakan angket, observasi dan dokumentasi.Data penelitian ini adalah nilai siswa menulis teks deskripsi. Dari hasil penelitian disimpulkan bahwa kemampuan dalam menulis teks deskripsi memperoleh nilai dengan kategori baik. Hal tersebut dapat dilihat dari nilai rata-rata siswa di atas KKM yang ditetapkan oleh sekolah. Berdasarkan hal tersebut, maka model Picture and Picture dapat diterapkan dalam pembelajaran menulis teks deskripsi pada siswa kelas VII SMP N 2 Kedu, Temanggung tahun ajaran 2017/2018. Saran yang dapat penulis sampaikan adalah guru sebagai fasilitator dalam pembelajaran diharapkan dapat menggunakan model pembelajaran yang kreatif, inovatif dan menyenangkan, khususnya dalam pembelajaran menulis teks deskripsi.
\end{abstract}

\begin{abstract}
This research is based on the writing skills are still low or below the average in class VII students of SMP N 2 Kedu Temanggung, especially writing description texts. Seeing these conditions, it is necessary to strive to use certain learning models to foster student motivation in learning to write descriptive texts in grade VII students of SMP N 2 Kedu Temanggung. One of them is by applying the Picture and Picture model.The formulation of the problem in this study is how is the application of the Picture and Picture model in learning to write description texts in grade VII students of SMP N 2 Kedu Temanggung in the 2018/2019 school year ?. There is also the purpose of this study to describe the application of the Picture and Picture model in learning to write description texts in class VII students of SMP N 2 Kedu Temanggung in the 2018/2019 school year. The form of research uses qualitative methods. Data collection techniques using test techniques to determine the results of writing description text using the Picture and Picture models and nontes techniques using questionnaires, observation and documentation. This research data is the value of students writing description text. From the results of the study concluded that the ability to write description texts get good grades. This can be seen from the average value of students above the KKM set by the school. Based on this, the Picture and Picture model can be applied in learning to write description texts in grade VII students of SMP N 2 Kedu, Temanggung for the academic year $2017 / 2018$. The suggestion that the writer can convey is that the teacher as a facilitator in learning is expected to be able to use creative, innovative and fun learning models, especially in learning to write description texts.
\end{abstract}

\footnotetext{
* Corresponding author. 


\section{PENDAHULUAN}

Pendidikan bukanlah proses yang diorganisasi secara teratur, terencana, dan menggunakan metode-metode yang dipelajari serta berdasarkan aturan-aturan yang telah disepakati mekanisme penyelenggaraan oleh suatu komunitas suatu masyarakat (Negara), melainkan lebih merupakan bagian dari kehidupan yang memang telah berjalan sejak manusia itu ada.Pendidikan bisa dianggap sebagai proses yang terjadi secara sengaja, direncanakan, didesain, dan diorganisasi berdasarkan aturan yang berlaku terutama perundang-undangan yang dibuat atas dasar kesepakatan masyarakat.Pendidikan sebagai sebuah kegiatan dan proses aktivitas yang disengaja merupakan gejala masyarakat ketika sudah mulai disadari pentingnya upaya untuk membentuk, mengarahkan, dan mengatur manusia sebagaimana dicita-citakan masyarakat (Omeri, 2015).

Dalam upaya meningkatkan mutu pendidikan diperlukan proses pembelajaran yang optimal untuk mencapai kompetensi. Uno (2011:75) menyatakan keberhasilan pencapaian kompetensi bergantung pada beberapa aspek. Salah satu aspek yang sangat mempengaruhi adalah bagaimana cara seorang guru dalam melaksanakan pembelajaran. Pembelajaran adalah sesuatu yang dilakukan oleh siswa, bukan dibuat oleh siswa. Pembelajaran merupakan upaya pendidik untuk membantu peserta didik melakukan kegiatan pembelajaran. (Yudasmini, 2015).

Salah satu keterampilan berbahasa adalah menulis. Menulis merupakan suatu keterampilan berbahasa yang digunakan untuk berkomunikasi secara tidak langsung, tidak secara tatap muka dengan orang lain. Menulis merupakan suatu kegiatan yang proaktif dan ekspresif (Tarigan, 2013: 3). Seseorang dikatakan terampil jika mampu menggunakan struktur kalimat. Keterampilan tersebut dapat diperoleh dengan berlatih secara teratur. Menulis dapat membantu mengembangkan daya kreativitas dalam mengumpulkan informasi yang telah terjadi dan dialami seseorang.

Pembelajaran merupakan proses interaksi antara individu dan lingkungan sekitarnya, yang artinya proses psikologi tidak terlalu banyak tersentuh di sini (Huda, 2014:6). Pembelajaran yang baik tentunya tidak lepas dari model pembelajaran yang sesuai untuk mencapai tujuan pembelajaran yang aktif. Selain model yang diterapkan oleh guru, strategi pembelajaran pun akan sangat berpengaruh dalam keberhasilan pembelajaran.

Seorang guru mempunyai peran penting dalam mencapai tujuan pembelajaran. Oleh karena itu, dibutuhkan perangkat pembelajaran berupa model pembelajaran yang sesuai dengan materi. Keberhasilan suatu pembelajaran ditentukan oleh beberapa faktor, diantaranya model pembelajaran, media pembelajaran dan situasi pemebelajaran yang sesuai dengan materi sehingga siswa akan menghasilkan belajar yang optimal. Dengan penerapan model pembelajaran yang tepat, siswa tertarik dengan materi yang disampaikan oleh guru. Siswa lebih bersemangat dan termotivasi untuk mengikuti proses belajar mengajar.

Model dan proses pembelajaran akan menjelaskan makna kegiatan-kegiatan yang dilakukan oleh pendidik selama pembelajaran berlangsung (Sagala, 2014:173). Penggunaan model yang tepat dalam pembelajaran sangatlah dibutuhkan. Tujuannya agar siswa lebih tertarik dan tidak merasa bosan dalam kegiatan belajar mengajar. Model pembelajaran yang tepat dan sesuai dengan materi pembelajaranakan menghasilkan ketepatan dalam proses belajar mengajar, sehingga siswa akan mengalami perubahan yang positif dalam pengetahuan, keterampilan, nilai, dan sikap.

Salah satu model yang dapat digunakan adalah Picture and Picture. Menurut Suprijono (dalam Huda, 2014: 236), model Picture and Picture merupakan strategi pebelajaran yang menggunakan gambar sebagai media pembelajaran. Kebaikan model Picture and Picture menurut (Hamdani, 2011:89) yaitu guru lebih mengetahui kemampuan tiap-tiap siswa dalam berlatih berpikir logis dan sistematis.

Berdasarkan hasil observasi yang dilakukan di SMP N 2 Kedu Temanggung, keterampilan menulis teks deskripsi pada siswa kelas VII SMP N 2 Kedu Temanggung kurang begitu baik. Siswa mampu memahami materi apa yang mereka pelajari tetapi untuk menuangkan ke dalam tulisan siswa kelas VII SMP N 2 Kedu Temanggung masih merasa kesulitan. Mereka hanya bisa menyimpan dalam pikiran mereka tentang ide-ide yang mereka punya.

Berdasarkan latar belakang di atas, maka peneliti mengambil judul "Penerapan Model Picture and Picture dalam Pembelajaran Teks Deskripsi pada Siswa Kelas VII SMP Negeri 2 Kedu Temanggung Tahun Ajaran 2018/2019".

\section{METODE PENELITIAN}

Jenis Langkah awal suatu proses penelitian adalah metode penelitian. Metode penelitian adalah rangkaian cara atau kegiatan yang didasari oleh landasan-landasan pikiran dasar, pandangan-pandangan 
filosofi, pandangan idiologi, pertanyaan, dan isu-isu yang dihadapi (Sukmadinata, 2010:213), menurut Sugiono (2010:3) metode penelitian adalah cara ilmiah untuk mendapatkan data dengan tujuan dan kegunaan tertentu.

Berdasarkan rumusan masalah yang dikemukakan, jenis penelitian ini adalah penelitian kualitatif. Metode penelitian kualitatif merupakan metode yang digunakan pada objek yang bersifat alamiah, peneliti sebagai kunci dari instrumen, teknik pengumpulan data dilakukan dengan gabungan, analisis data bersifat induktif, hasil penelitian lebih menekankan makna dari pada generalisasi dan pada metode kualitatif ini lawannya adalah eksperimen (Sugiyono, 2015:15)

\section{ANALISIS DAN PEMBAHASAN}

\section{A. Observasi}

Observasi untuk mengamati proses penggunaan model Picture and Picture dalam pembelajaran menulis teks deskripsi dilaksanakan oleh guru bahasa Indonesia di dalam kelas saat pembelajaran berlangsung. Untuk mengetahui hasil observasi dilakukan pengamatan secara langsung dan sesuai lembar observasi yang telah ditentukan. Pengamatan meliputi kegiatan awal, kegiatan inti, dan kegiatan akhir. Berikut penjelasan observasi dari penggunaan model Picture and Picture dalam pembelajaran menulis teks deskripsi.

\section{Proses Pembelajaran}

Observasi selama proses penggunaan model Picture and Picture dalam pembelajarann menulis teks deskripsi berlangsung kondusif, aktif, dan responsif. Sebelum mengajar guru membuat RPP untuk menjadi paduan mengajar. Memasuki pembelajaran, siswa dikondisikan mempersiapkan diri menerima pembelajaran. Dimulai dengan guru membuka salam, presensi siswa, berdoa yang dipimpin oleh guru, menyampaikan tujuan pembelajaran. Melakukan apersepsi tentang teks deskripsi sehingga siswa mempunyai pengetahuan awal sebelum memasuki materi. Selain itu, guru juga menjelaskan tentang manfaat belajar materi teks deksripsi.

Pada kegiatan inti, guru menyajikan materi terkait dengan pembelajaran. Siswa memperhatikan gambar contoh teks deksripsi di layar LCD serta mengamati aspek makna kebahasaan yang diberikan oleh guru. Penggunaan gambar pada pembelajaran bertujuan agar siswa dapat fokus. Setelah siswa menyimak gambar, guru bertanya kepada siswa tentang pengetahuan dan pengalaman siswa tentang menulis teks deskripsi. Guru menumbuhkan partisipasi aktif peserta didik melaui interaksi guru, siswa, sumber belajar dan kegiatan tanya jawab. Siswa menjawab pertanyaan dan mencari sumber mengenai segala sesuatu yang berhubungan dengan menulis teks deskripsi. Siswa menulis teks deksripsi secara sistematika berdasarkan unsur kebahasaan. Siswa menulis teks dekripsi sesuai tema yang ditentukan. Beberapa siswa (yang dipersilakan secara acak) secara bergiliran mempresentasikan hasil kerja mereka, sedangkan siswa yang lain merespon/menanggapi. Siswa menyimpulkan materi pembelajaan yang telah dipelajari.

Selama mengikuti pembelajaran, siswa aktif dan tidak bosan karena pengu naan model Picture and Picture dapat membuat siswa senang dan membantu memudahkan siswa dalam memahami materi. Selain itu, waktu pembelajaran dilakukan di pagi sekitar pukul 10.00 WIB sehingga siswa yang kurang bersemangat menjadi bersemangat kembali.

Di akhir kegiatan, guru memberikan evaluasi dan motivasi kepada siswa mengenai teks deskripsi serta memberikan penugasan untuk menambahkan kemampuan siswa dalam pembelajaran menulis teks deskripsi. Siswa merefleksi penugasan materi yang telah dipelajari dan bersama guru mengevaluasi pembelajaran. Guru menutup pembelajaran dengan berdoa bersama dan mengucap salam.

\section{Respon Siswa}

Setelah memperoleh hasil kemampuan menulis teks deskripsi tersebut, diperoleh juga hasil angket guru dan siswa. Hasil angket perilaku atau sikap siswa dalam kegiatan pembelajaran menulis teks deskripsi dengan menggunakan model Picture and Picture meliputi keaktifan siswa dalam memperhatikan pelajaran, antusias siswa dalam mengikuti pelajaran, konsentrasi siswa dalam mendengarkan penjelasan guru, keaktifan siswa selama proses pembelajaran, dan keaktifan mengerjakan tugas yang diberikan guru. Respon positif siswa terhadap penjelasan guru ditunjukkan dari sikap siswa yang tampak serius memperhatikan penjelasan guru dan keaktifan siswa dalam kegiatan menulis teks deskripsi karena dengan gambar yang diberikan guru siswa lebih tertarik untuk menegerjakan.

Pada saat pembelajaran siswa sangat serius memeperhatikan pembelajaran menulis teks deskripsi. Keseluruhan respon yang diberikan siswa adalah respon positif. Hal ini terlihat dari kesungguhan siswa dalam mengerjakan tugas teks deskripsi. 
Dalam memahami materi pembelajaran pastinya setiap siswa berbeda-beda tingkat pemahaman terhadap materi dengan sumber yang disajikan guru, begitu juga dalam pembelajaran menulis teks deskripsi dengan menggunakan model Picture and Picture. Akan tetapi seluruh siswa yang berjumlah 20 merasa paham atas materi yang disampaikan oleh guru.

Penerapan model Picture and Picture dalam menulis teks deskripsi memberikan manfaat bagi siswa. Siswa berpendapat pembelajaran yang diberikan guru kali ini lebih menarik dari pada ceramah. Mereka merasa senang dalam mengikuti pembelajaran.

Berdasarkan respon-respon yang ditunjukkan siswa dalam pembelajaran menulis teks deskripsi, diperoleh hasil baik, artinya penerapan model Picture and Picture tepat digunakan dalam pembelajaran menulis teks deskripsi pada siswa kelas VII SMP 2 Kedu, Temanggung tahun ajaran 2018/2019.

\section{B. Dokumentasi}

Pengumpulan data yang digunakan dalam penelitian ini adalah dokumentasi. Dokumentasi diperlukan untuk memperkuat data-data yang telah diperoleh sehingga data akurat. Dokumentasi diperlukan sebagai bukti yang valid bahwa peneliti sudah melakukan penelitian terhadap kelas VII SMP N 2 Kedu, Temanggung dengan pembelajaran menulis teks deksripsi menggunkan model Picture and Picture. Hasil dokumentasi diambil ketika proses belajar mengajar berlangsung, sebagai tanda bukti visual. Hasil dokumentasi berupa daftar hadir siswa yang berjumlah 20 siswa terdiri dari 10 perempuan dan 10 laki-laki, hasil lembar teks menulis teks deskripsi siswa, dan lembar observasi guru. Seluruh dokumentasi yang mendukung data penelitian terpapar dalam daftar lampiran. Selain itu, hasil dokumentasi ini didukung dengan foto-foto yang diambil dalam penelitian menggunakan model Picture and Picture dalam pembelajaran menulis teks deskripsi.

Hasil tes adalah hasil yang diperoleh siswa setelah menulis teks deskripsi. Beberapa hal yang harus diperlihatkan dalam menulis teks deksripsi yaitu (1) struktur teks (2) urutan (3) diksi (4) penggunaan EYD dalam menulis teks dekripsi.

Empat aspek yang telah disebutkan terdiri dari soal teks uraian. Skor maksimal yang akan didapat oleh siswa yaitu 100 dengan perhitungan nilai akhir terdiri dari nilai tes uraian. Tingkat keberhasilan siswa dalam menulis teks deskripsi dapat dilihat dari kriteria ketuntasan KKM yaitu 75.

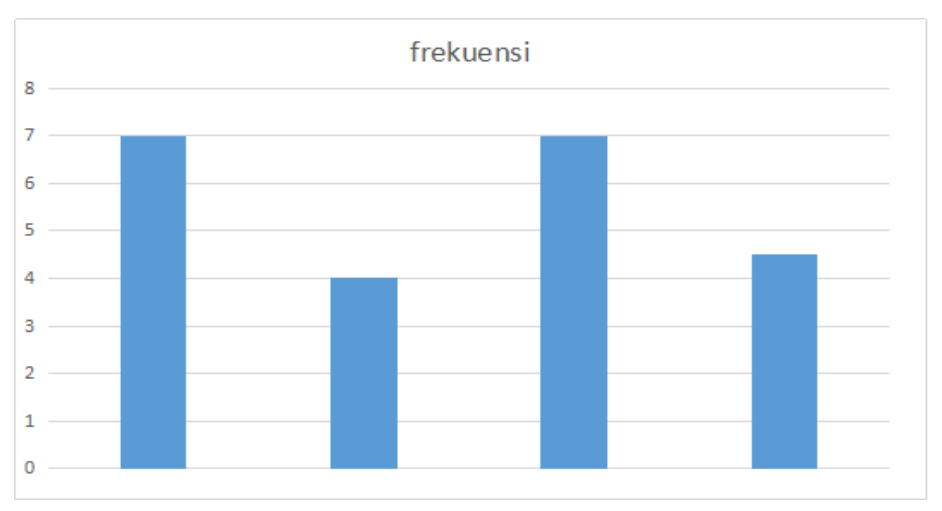

Gambar 1. Diagram Hasil Diagram Batang Menulis Teks Deskripsi

Penelitian ini bertujuan untuk mengetahui penerapan model Picture and Picture dalam pembelajaran menulis teks deskripsi pada siswa kelas VII SMP N 2 Kedu tahun ajaran 2018/2019. Tahap awal yang dilakukan oleh peneliti sebelum melakukan penelitian yaitu observasi langsung ketempat penelitian yaitu SMP N 2 Kedu. Setelah itu peneliti melakukan konsultasi dengan guru mata pelajaran Bahasa Indonesia untuk menentukan kelas yang akan digunakan penelitian yaitu kelas VII A. Setelah kelas ditentukan, selanjutnya menyiapkan perangkat pembelajaran dan instrumen penelitian yang akan digunakan untuk penelitian dan peneliti melakukan penelitian menggunakan model Picture and Picture dalam menulis teks deskripsi.

Model Picture and Picture digunakan di kelas VII A karena model tersebut merupakan model yang mudah diterapkan di berbagai jenjang pendidikan. Selain itu, model Picture and Picture dapat digunakan sebagai sarana penyampaian materi pembelajaran berupa tayangan gambar yang mempunyai daya tarik tersendiri sehingga mempermudah siswa dalam memahami serta menyampaikan ide dan gagasan.

Kegiatan pembelajaran dimulai dengan guru melakukan apersepsi kemudian guru menyajikan dan menampilkan materi terkait dengan pembelajaran yang diajarkan kepada siswa. Model Picture and Picture berupa gambar cerita tentang lingkungan hidup. Setelah guru menyajikan dan menampilkan materi, siswa diminta untuk mengerjakan soal tes yang diberikan secara individu. Di akhir pembelajaran dilakukan 
evaluasi hasil pekerjaan siswa dalam menjawab soal tes. Semua kegiatan pemebalajaran dengan monitoring guru. Guru dapat memposisikan sebagai fasilitator bagi siswanya karena dalam kegiatan dengan model Picture and Picture siswa diberikan tanggung jawab penuh terhadap proyek yang diberikan guru. Selain itu guru dapat memonitoring siswa-siswa setiap tahap pembelajarannya sehingga dapat diketahui perkembangan individu dalam pembelajaran.

Lembar soal yang diberikan kepada siswa berupa tes uraian. Beberapa kriteria diberikan yang harus dipenuhi antara lain siswa dapat menjawab pertanyaan soal tes sesuai dengan tema, objek berasal dari lingkungan hidup, dan isi sesuai dengan ejaan, tanda baca dan isi, serta struktur teks deskripsi. Dari hasil tes, data yang digunakan untuk mengetahui penerapan model Picture and Picture dalam pembelajaran menulis teks dekskripsi di kelas VII A yang berjumlah 20 siswa. Diperoleh skor tertinggi kelas VII A yaitu 87, skor terendah 60, dan skor rata-rata 75,3 sehingga telah mencapai ketuntasan belajar di atas KKM yaitu 75. Berdasarkan perhitungan interval kelas dengan rumus diketahui bahwa rentang data 27 jumlah kelas interval 5 dan panjang interval 5.

Tabel 1. Daftar Nilai Siswa

\begin{tabular}{|c|c|c|c|c|}
\hline No. & Nama Siswa & $\mathrm{L} / \mathrm{P}$ & Jumlah Skor & Skor Akhir \\
\hline 1. & Afriyadi & $\mathrm{L}$ & 34 & 85 \\
\hline 2. & Aldi Viriya Putra & $\mathrm{L}$ & 24 & 60 \\
\hline 3. & Annisa Melviani & $P$ & 30 & 75 \\
\hline 4. & Arif Fauzi & $\mathrm{L}$ & 27 & 67 \\
\hline 5. & Desti Armadani & $\mathrm{P}$ & 34 & 85 \\
\hline 6. & Dewi Ruqoyah & $P$ & 30 & 75 \\
\hline 7. & Didid Darmawan A. & $\mathrm{L}$ & 30 & 75 \\
\hline 8. & Imas Dinaryanti & $\mathrm{P}$ & 35 & 87 \\
\hline 9. & Indhi Sugiarti & $\mathrm{P}$ & 29 & 72 \\
\hline 10. & Indra Lukmatul Kh & $\mathrm{L}$ & 25 & 62 \\
\hline 11. & Indra Pamungkas & $\mathrm{L}$ & 29 & 72 \\
\hline 12. & Kusumaningrum & $\mathrm{P}$ & 34 & 85 \\
\hline 13. & Lintang Avrelian & $\mathrm{P}$ & 35 & 87 \\
\hline 14. & Lutfiyanto Fatkhurahman & $\mathrm{L}$ & 28 & 70 \\
\hline 15. & Meika Dwi S. & $\mathrm{P}$ & 35 & 87 \\
\hline 16. & Muhammad Ariya P. & $\mathrm{L}$ & 30 & 75 \\
\hline 17. & Nadia Agis Ramadhani & $P$ & 29 & 72 \\
\hline 18. & Riska Marselinda & $\mathrm{P}$ & 34 & 85 \\
\hline 19. & Samsul Ma'arif & $\mathrm{L}$ & 26 & 65 \\
\hline 20. & Sutiyo Giarto & $\mathrm{L}$ & 26 & 65 \\
\hline
\end{tabular}

Berdasarkan hasil angket siswa dari proses kegiatan pembelajaran menulis teks deskripsi menggunakan model Picture and Picture jumlah skor tertinnggi yaitu 35 dari 3 orang dengan skor 87, sedangkan skor terendah yaitu 24 dari 1 orang dengan nilai 60. Dari angket 20 siswa, rata-ratanya adalah 75,3. Hasil perhitungan dapat diketahui bahwa rentang skor yang dimiliki oleh kelas VII A adalah 27 dan interval kelasnya 5. Ditribusi angket kegiatan siswa dalam proses belajar mengajar mendapat nilai antara interval 85-100 berjumlah 7 siswa dengan presentase 35\%, interval 75-84 berjumlah 4 siswa dengan presentase 20, interval 65-74 berjumlah 7 siswa dengan presentase 35\%, dan interval 50-64 berjumlah 2 siswa dengan presentase 10\%. Dari hasil perhitungan siswa, dapat disimpulkan bahwa dengan model Picture and Picture dapat digunakan dalam pembelajaran menulis teks deksripsi. Penggunaam model Picture and Picture dapat mempermudah siswa mnegerjakan tugas yang diberikan oleh guru dan siswa juga lebih aktif untuk mengeluarkan ide-ide, sehingga pembelajaran di kelas menjadi lebih efektif dan menyenangkan.

Dari beberapa pertanyaan yang diajukan peneliti diperoleh hasil bahwa siswa menunjukkan respon positif dan timbul perasaan yang senang dengan adanya metode tersebut. Berbagai alasan yang dikemukakan siswa antara lain mudah menemukan ide dalam menulis teks deskripsi, tidak merasa kesulitan dalam menerima pada saat pembelajaran menulis teks deskripsi, menarik siswa untuk mengikuti pembelajaran dan lebih memahami materi yang disampaikan oleh guru. 
Ada pun dokumentasi untuk melengkapi hasil dari kegiatan proses pembelajaran menulis teks deskripsi ,terdapat hasil lainnya antara lain daftar hadir siswa, daftar nilai dan dokumentasi foto proses pembelajaran. Daftar hadir diperoleh dari kehadiran siswa yang mengikuti proses pembelajaran. Daftar nilai diperoleh dari hasil tes menulis teks deskripsi. Dalam hal ini, daftar nilai digunakan untuk mengetahui pemahaman siswa mengenai materi yang sudah digunakan dengan menggunakan model Picture and Picture dan menjadi tolok ukur bahwa penelitian tersebut berhasil atau tidak. Dokumentasi foto digunakan sebagai bukti bahwa peneliti telah melakukan penelitian tersebut. Berikut daftar nilai yang diperoleh siswa dalam menulis teks deskripsi.

Dengan demikian terbukti bahwa penggunaan model Picture and Picture dalam pembelajaran menulis teks dekripsi pada siswa kelas VII SMP N 2 Kedu tahun ajaran 2018/2019 cukup berhasil, dapat dilihat dari kemampuan dalam menyelesaikan soal menulis teks deskripsi dan siswa antusias dalam mengikuti pembelajaran

\section{KESIMPULAN}

Berdasarkan hasil penelitian yang dilakukan pada siswa kelas VII SMP N 2 Kedu dapat disimpulkan bahwa model Picture and Picture dapat diterapkan dalam pembelajaran menulis teks deskripsi.

Hal ini dapat dilihat dari hasil perhitungan angket menulis teks deskripsi dengan menggunakan model Picture and Picture, jumlah skor tertinggi yaitu 35 dari 3 siswa dengan nilai 87, sedangkan jumlah skor terendah yaitu 24 dari 1 siswa dengan nilai 60 . Hal itu ditunjukkan dengan kelas yang aktif dan siswa lebih berkonsentrasi dalam mengikuti pembelajaran. Siswa antusias dalam mengikuti pembelajaran dan bersungguh-sungguh mmengerjakan tugas dengan baik. Siswa juga dapat menjawab pertanyaan yang diberikan oleh guru. Dari hasil perhitungan angket siswa, dapat disimpulkan bahwa model Picture and Picture dapat digunakan dalam pembelajaran menulis teks deksripsi. Model Picture and Picture dapat digunakan siswa mengerjakan tugas yang diberikan oleh guru dan siswa juga lebih aktif untuk mengeluarkan ide-ide, sehingga pembelajaran di kelas menjadi lebih efektif dan menyenangkan Berdasarkan perhitungan kemampuan siswa dalam menulis teks deskripsi dengan menggunakan model Picture and Picture di kelas VII A yang berjumalah 20 siswa. Diperoleh nilai tertinggi kelas VII A yaitu 87, nilai terendah 60 dan nilai rata-rata 75,3 sehingga telah mencapai ketuntasan hasil belajar diatas KKM 75. Berdasarkan perhitungan interval kelas dan rumus diketahui bahwa rentang data 27, jumlah kelas interval 5 dan panjang interval 5.

Dapat disimpulkan bawa dalam mata pelajaran Bahasa Indonesia terutama dalam pembelajaran menulis teks deskripsi dengan menggunakan model Picture and Picture merupakan cara menulis teks deskripsi yang menyenangkan. Di samping itu hasil evaluasi menunjukkan bahwa siswa mampu menulis teks deskripsi dengan bukti nilai yang diperoleh. Dengan demikian dapat disimpulkan bahwa model Picture and Picture dapat diterapkan dalam pembelajaran menulis teks deskripsi pada siswa kelas VII SMP N 2 Kedu, Temanggung tahun ajaran 2018/2019

\section{DAFTAR PUSTAKA}

Arikunto, Suharsimi. 2013. Prosedur Penelitian Suatu Pendekatan Praktik. Jakarta; Rineka Cipta.

Arikunto. 2013. Dasar-dasar Evaluasi Pendidikan. Jakarta:Bumi Aksara.

Dalman. 2018. Keterampilan Menulis. Jakarta: Raja Grafindo Persada

Hamdani. 2011. Strategi Belajar Mengajar. Bandung: Pustaka Setia.

Hamdayana, Jumanta. 2014. Model dan Metode Pembelajaran Kreatif dan Berkarakter. Bogor: Ghalia Indonesia.

Herdiansyah. 2013. Wawancara, Observasi, dan Focus Groups. Jakarta:Rajawali Pers.

Huda, Miftahul. 2014. Model-Model Pengajaran dan Pembelajaran. Bandung: Pustaka Setia.

Kokasih. 2014. Dasar-dasar Keterampilan Menulis. Bandung: yrama Widya

Hamid 
Nurgiyantoro, Burhan. 2010. Penilaian dalam Pengajaran Bahasa dan Sastra. Yogyakarta:BPFE. Sagala, Syaiful. 2014. Konsep dan Makna Pembelajaran. Bandung: Alfabeta.

Omeri, Nopan. 2015. Pentingnya Pendidikan Karakter Dalam Dunia Pendidikan . Jurnal Manajer Pendidikan, Volume 9, Nomor 3, Juli 2015

Sugiyono. 2015. Metode Penelitian Pendidikan. (Pendekatan Kualitatif, Kuantitatif, dan R \& D). Bandung: Alfabeta.

Sukmadinata. 2012. Metode Penelitian Pendidikan. Bandung: PT Remaja Rosdakarya.

Tarigan, Hery Guntur. 2013. Menulis Sebagai Suatu Keterampilan Berbahasa. Bandung: Angkasa.

Yudasmini, Ni M . 2015. Pengaruh Model Pembelajaran Circ (Cooperative Integrated Reading And Composition) Terhadap Minat Baca Dan Kemampuan Memahami Bacaan Pada Siswa Kelas Vi Di Sekolah Dasar Gugus Buruan . e-Journal Program Pascasarjana Universitas Pendidikan Ganesha Program Studi Penelitian dan Evaluasi Pendidikan (Volume 5, No 1 Tahun 2015)

Zainurrahmat. 2018. Menulis Dari Teori Hingga Praktik ( Penawar Racun Plagiarisme). Bandung: Alfabeta. 